\title{
PENGGUNAAN GAME BASED LEARNING QUIZIZZ UNTUK MENINGKATKAN KEAKTIFAN BELAJAR SISWA PADA MATA PELAJARAN SOSIOLOGI MATERI GLOBALISASI KELAS XII IPS SMA DARUL HIKMAH KUTOARJO
}

\author{
Setyo Edy Pranoto ${ }^{1}$
}

\begin{abstract}
Abstrak
Teknik pengajaran konvensional cenderung membuat pelajaran membosankan karena suasana proses pembelajaran tidak menarik dan cenderung peserta didik sulit untuk fokus pada proses pembelajaran, sama halnya terjadi di SMA Darul Hikmah Kutoarjo. Peserta didik cenderung bosan dengan pembelajaran tersebut, sehingga peneliti mencarai alternatif untuk meningkatkan keaktifan peserta didik dalam proses pembelajaran yaitu dengan game based learning quizizz. Proses pembelajaran dan pengajaran yang kondusif, menyenangkan dan tidak membosankan bagi peserta didik di dunia pendidikan dibutuhkan agar maksud dan tujuan pengajaran yang diharapkan dapat dicapai. Quizizz merupakan satu di antara media pembelajaran yang berbentuk kuis dan berbasis 4.0. Quizizz dapat dijadikan pilihan oleh guru sebagai media pembelajaran karena berbasis permainan dan teknologi. Tujuan penelitian ini adalah meningkatkan keaktifan peserta didik dalam proses pembelajaran. Penelitian ini menggunakan metode Penelitian Tindakan Kelas (PTK), teknik pengumpulan data menggunakan observasi mendalam dengan lembar observasi mengenai keaktifan peserta didik. Berdasarkan hasil analisis data penelitian, keaktifan peserta didik dalam proses pembelajaran sebelum diberikan perlakuan tingkat keaktifan siswa hanya $10 \%$ dengan kategori tinggi, $10 \%$ sedang dan $80 \%$ rendah, dan setelah diberikan perlakuan sampai dengan siklus ke III diperoleh nilai hitung keaktihan siswa mencapai $82 \%$ dengan kategori tinggi, 18 sedang dan $0 \%$ rendah. Ini menunjukkan adanya perbedaan signifikan pada keaktifan peserta didik dalam proses pembelajaran, sehingga dapat disimpulkan bahwa penggunaan game based learning quizizz terbukti meningkatkan keaktifan peserta didik dalam proses pembelajaran Sosiologi.
\end{abstract}

Kata Kunci: Game based learning, Quizizz, Keaktifan.

\footnotetext{
${ }^{1}$ Guru Sosiologi, SMA Darul Hikmah Kutoarjo, Indonesia email: setyo.edy12@gmail.com
} 


\section{PENDAHULUAN}

Belajar adalah kunci yang sangat penting dalam setiap usaha pendidikan. Pendidikan suatu hal yang sangat penting bagi kehidupan manusia dalam rangka mencerdaskan kehidupan bangsa. Pendidikan mempunyai peranan yang penting dalam memperbaiki kualitas sumber daya manusia. Di dalam Undang-Undang No. 20 Tahun 2003 tentang sistem pendidikan nasional bahwa: Pendidikan adalah usaha sadar dan terencana untuk mewujudkan suasana belajar dan proses pembelajaran agar peserta didik secara secara aktif mengembangkan potensi dirinya untuk memiliki kekuatan spiritual keagamaan, pengendalian diri, kepribadian, kecerdaasan, akhlak mulia, serta keterampilan yang diperlukan dirinya, masyarakat, bangsa dan negara.

SMA Darul Hikmah Kutoarjo melaksanakan proses pembelajaran dan pengajaran yang kondusif, menyenangkan dan tidak membosankan bagi peserta didik di dunia pendidikan dibutuhkan agar maksud dan tujuan pengajaran yang diharapkan dalam proses pembelajaran mudah dicapai. Era
Revolusi Industri 4.0 yang tengah melanda segala kehidupan menjadikan lembaga pendidikan harus mampu beradapatasi dengan perkembangan teknologi, salah satunya menjadikannya dalam proses pembelajaran yang kondusif dan menyenangkan. SMA Darul Hikmah pada tahun pelajaran 2020/2021 dalam rangka memberikan pembelajaran daring/jarak jauh (PJJ) berusaha untuk memberikan pelayanan yang terbaik, di sekolah kami telah menggunakan aplikasi yang mendorong kedisiplinan anak dan pengecekan aktivitas secara riil seperti google meet, zoom, Microsoft 36 dan aplikasi pembelajaran seperti Google Class Room, tetapi platform tersebut lamakelamaan juga membuat kegiatan anak setiap harinya tersas jenuh, mungkin karena tidak adanya kreatifitas dan hanya itu-itu saja yang ditampilkan. Penggunaan internet untuk keperluan pendidikan yang semakin meluas terutama negara-negara maju, merupakan fakta yang menunjukkan bahwa dengan media ini memang memungkinkan diselenggarakannya proses belajar mengajar yang lebih 
efektif (Hardjito, 2002). Sebagai media yang diharapkan akan menjadi bagian dari suatu proses belajar mengajar di sekolah, internet harus mampu memberikan dukungan bagi terselenggaranya proses komunikasi interaktif antara guru dengan siswa sebagaimana dipersyaratkan dalam suatu kegiatan pembelajaran.

Konsep dalam penelitian ini mengacu pada game based learning yang merupakan teknik pembelajaran berlandasan permainan yang dapat membantu meningkatkan potensi dan kualitas pelajar dalam menyerap pengetahuan. Ryan Dellos (2015), menyatakan bahwa pembelajaran berlandasan permainan merupakan alat yang dapat membantu peserta didik dalam menyelesaikan masalah, meningkatkan pemikiran kritis dan membuat sebuah penilaian dalam proses pembelajaran. Pada tahun pelajaran 2020/2021 pembelajaran di SMA Darul Hikmah Kutoarjo masih minim dalam penggunaan aplikasi interaktif untuk menarik perhatikan dari peserta didik. Guru hanya menggunakan media papan tulis dan power point sebagai media dalam menjelaskan materi kepada peserta didik. Dalam kegiatan pembelajaran guru selalu memberikan pertanyaan kepada siswa untuk menguji apakah siswa tersebut fokus terhadap pelajaran yang sedang diikuti, akan tetapi ketika guru memberikan pertanyaan respon siswa kurang antusias untuk menjawab pertanyaan. karena pelajaran sosiologi dianggap membosankan dan tidak menyenangkan. Dari fakta - fakta diatas guru perlu upaya untuk mengatasi permasalahan tersebut agar peserta didik bisa berperan dan aktif dalam proses pembelajaran. Salah satu upaya yang dilakukan adalah menggunakan metode gamebased learning dengan aplikasi interaktif quizizz untuk meningkatkan keaktifan belajar siswa pada mata pelajaran sosiologi materi globalisasi kelas XII IPS. Penelitian ini dirancang dan bertujuan untuk mengetahui tingkat keaktifan siswa dalam pembelajaran sosiologi dengan menggunakan model gamebased learning, mengetahui sistem aplikasi pembelajaran interaktif yang lebih baik dibandingkan dengan model konvensional dalam meningkatkan 
keaktifan siswa dalam proses

pembelajaran. Penelitian ini menggunakan metode Penelitian Tindakan Kelas (PTK), teknik pengumpulan data menggunakan observasi mendalam dengan lembar observasi mengenai keaktifan peserta didik.

Penggunaan aplikasi interaktif (game) seperti Quizizz ini sesungguhnya mempermudah guru dalam mengelola pembelajaran dan menyampaikan informasi secara cepat dan akurat kepada siswa. Quizizz merupakan sebuah web untuk membuat permainan kuis interaktif yang bisa digunakan dalam pembelajaran dikelas (bisa digunakan untuk evaluasi pembelajaran). Quizizz sekarang bisa diakses di playstore bagi pengguna android, sehingga dalam penggunaannya lebih praktis dan tentunya mobile friendly. (diambil dari https://smartsosiologi.com/jadi-guru-

\section{millenial-buat-kuis-online-dengan-}

aplikasi-quizizz/ dikakses pada senin, tanggal 13 Oktober 2020 pukul 14.00) Quizizz hampir sama dengan Quipper dan kahoot karena merupakan media pendidikan yang berbasis elearning semacam kelas online. Berdasar hasil wawancara yang dilakukan dengan Guru seluruh guru mata pelajaran yang mengampu di kelas XII IPA maupun IPS SMA Darul Hikmah Kutoarjo, pada tanggal 13 Oktober 2020, disebutkan bahwa media pembelajaran berpangaruh terhadap motivasi dan hasil belajar siswa. Guru perlu mengatahui kriteria media yang harus digunakan agar dapat disenangi dan diterima oleh siswa, karena hal tersebut akan berpengaruh pada tingkat keaktifan siswa dalam proses belajar mengajar. Perlu adanya penggunaan media yang inovatif dan interaktif oleh guru yang dapat membuat siswa tidak sadar bahwa ia sedang belajar sambil bermain. Perlu adanya penyesuaian media pembelajaran dengan kondisi dan kebutuhan siswa.

Keaktifan belajar adalah suatu usaha atau kegiatan yang dilakukan dengan giat belajar. (Hamalik, 2008) keaktifan belajar adalah suatu keadaan atau hal siswa dapat aktif dalam pembelajaran. Bentuk bentuk keaktifan siswa dalam pebelajaran dapat dilihat dari keterlibatan siswa dalam proses 
pembelajaran, seperti diskusi, mendengarkan penjelasan, memecahkan masalah, aktif mengerjakan tugas membuat laporan dan mampu mempresentasikan hasil laporan. Sedangkan faktor yang mempengarugi keaktifan belajar menurut. Menurut Gagne dan Briggs (dalam Martinis, 2007) faktor-faktor keaktifan belajar adalah memberikan dorongan atau menarik perhatian siswa, menjelaskan tujuan intruksional (kemampuan dasar kepada siswa), mengingatkan kompetensi belajar kepada siswa, memberikan stimulus (masalah,topik dan konsep yang akan dipelajari), memberi petunjuk kepada siswa cara mempelajarinya, memunculkan aktivitas, partisipasi siswa dalam kegiatan pembelajaran, memberi umpan balik (feed back), melakukan tes singkat diakhir pembelajaran,dan menyimpulkan setiap materiyang disampaikan di akhir pelajaran. Adapun indikator keaktifan belajar adalah mampu memecahkan masalah, mampu bekerjasama, mampu mengemukkakan pendapat, mampu mengemukakan gagasan atau ide dan perhatian.

\section{METODE PENELITIAN}

Metode yang digunakan dalam penelitian ini adalah Penelitian Tindakan Kelas (PTK). Ebbut (Wiriaatmadja, 2009:12) mengemukakan bahwa penelitian tindakan adalah kajian sistematik dari upaya perbaikan pelaksanaan praktek pendidikan oleh sekelompok guru dengan melakukan tindakan-tindakan dalam pembelajaran, berdasarkan refleksi mereka mengenai hasil dari tindakantindakan tersebut. Model penelitian yang digunakan dalam penelitian ini adalah model siklus Kemmis dan Taggart yang terdiri dari empat komponen yaitu perencanaan, tindakan, observasi, dan refleksi. Penelitian ini dilakukan pada materi Globalisasi dan perubahan komunitas lokal. Subyek penelitian adalah siswa kelas XII IPS SMA Darul Hikmah Kutoarjo yang melibatkan 11 siswa. Penelitian dilakukakan sejak sejak tanggal 22 Oktober sampai tanggal 13 November tahun 2020. Instrumen pengumpulan data adalah lembar observasi pelaksanaan proses pembelajaran daring melalui aplikasi quiziz, sedangkan teknis analisis data 
menggunakan teknik analisis deskriptif kualitatif dan kualitatif menggunakan kreteria pencapaian.

\section{HASIL}

Berdasarkan penelitian yang telah dilakukan diperoleh hasil yaitu berupa peningkatan keaktifan peserta didik dalam proses pembelajaran dengan pemaparan sebagai berikut : Penelitian ini dilakasanakan melalui tahap pra siklus serta 2 siklus yaitu siklus I dan siklus II masing masing siklus ada 2 kali pertemuan. Tahapan penelitian yang dilakukan pada siklus I pertemua ke-1 adalah (1) tahap perencanaan yaitu menyiapkan RPP, lembar observasi, media pembelajaran dan aplikasi quizizz (2) tahap pelaksanaan yaitu share link google meet di whatsapp grup, memulai pembelajaran dengan video dan post test dengan quizizz (3) tahap observasi melihat hasil pengerjaan quizizz (4) refleksi. Tahap tahap ini juga dilakukan untuk pertemuan yang ke-2. Tahaptahap penelitian ini sedikit sulit untuk dilakukan, mengingat secara daring yang kita tidak bisa melihat keaktifan siswa secara langsung. Dari observasi siklus pertama, siswa dalam melaksanakan kegiatan pembelajaran Sosiologi siklus
I, tampak pada indikator keaktifan siswa dalam kategori pembelajaran, tanya jawab dan pengerjaan kuis. Keaktifan dapat diketahui peningkatannya sebelum dilakukan tindakan (Pra Siklus) pada kategori "rendah" yaitu 5,0 setelah diperlakuan menggunakan pendekatan dengan model game based learning skor rata-ratanya meningkat menjadi 8,0 dengan kategori "sedang". Hasil yang diperoleh sebagian besar siswa menunjukkan keaktifan yang lebih baik dibandingkan dengan keaktifan siswa pada saat observasi awal sebelum tindakan. Hal ini menunjukkan bahwa keaktifan belajar siswa di kelas XII IPS dalam mata pelajaran Sosiologi meningkat. Berdasarkan hasil observasi pertemuan ke-1 dari 11 siswa hanya 4 (36,36\%) orang yang aktif (kategori tinggi dan sedang), hal ini dapat dilihat dari hasil unduhan siswa yang mengerjakan kuis. Pertemuan ke-2 siswa yang aktif mengerjakan kuis 2 sebanyak 7 ( 63,63\%) siswa. Pada siklus I pertemuan ke-1 dan ke-2 rata-rata $50,13 \%$ yang aktif (kategori tinggi dan sedang). 
Tabel 1. Katagori Tingkat Keatifan Belajar

Siswa

\begin{tabular}{|c|c|c|}
\hline No & $\begin{array}{c}\text { Rentang } \\
\text { Skor }\end{array}$ & Kategori \\
\hline 1 & $\begin{array}{c}85 \%- \\
100 \%\end{array}$ & $\begin{array}{c}\text { Sangat } \\
\text { Tinggi }\end{array}$ \\
\hline 2 & $69 \%-84 \%$ & Tinggi \\
\hline 3 & $53 \%-68 \%$ & Cukup \\
\hline 4 & $37 \%-52 \%$ & Rendah \\
\hline 5 & $20 \%-36 \%$ & $\begin{array}{c}\text { Sangat } \\
\text { Rendah }\end{array}$ \\
\hline
\end{tabular}

Table 2. Pengkategorian Tingkat Keaktifan Siswa

\begin{tabular}{|c|c|}
\hline $\begin{array}{c}\text { Pengkatego } \\
\text { rian Skor } \\
\text { Keaktifan } \\
\text { Siswa }\end{array}$ & Kategori \\
\hline $11-15$ & Tinggi \\
\hline $6-10$ & Sedang \\
\hline $0-5$ & Rendah \\
\hline
\end{tabular}

Table 3. Skor Hasil Observasi Keaktifan Siswa Siklus I

\begin{tabular}{|l|l|c|c|}
\hline No & \multicolumn{1}{|c|}{ Nama } & $\begin{array}{c}\text { Hasil } \\
\text { observas } \\
\text { i Siklus } \\
\text { I }\end{array}$ & $\begin{array}{c}\text { Kriteria } \\
\text { Keaktifan }\end{array}$ \\
\hline 1 & $\begin{array}{l}\text { Aldika } \\
\text { Rambu } \\
\text { Perdana }\end{array}$ & 8 & Rendah \\
\hline 2 & $\begin{array}{l}\text { Dhimas } \\
\text { Putra Aji } \\
\text { P }\end{array}$ & 12 & Tinggi \\
\hline 3 & $\begin{array}{l}\text { Erlangga } \\
\text { Yuna } \\
\text { Nirboyo }\end{array}$ & 6 & Rendah \\
\hline 4 & $\begin{array}{l}\text { Fharaz } \\
\text { Ramadha } \\
\text { naman }\end{array}$ & 7 & Sedang \\
\hline 5 & $\begin{array}{l}\text { Gibran } \\
\text { Rizqi Al } \\
\text { Baqi }\end{array}$ & 6 & Rendah \\
\hline 6 & Khosim & 9 & Sedang \\
\hline
\end{tabular}

\begin{tabular}{|c|c|c|c|}
\hline & $\begin{array}{l}\text { Muhamm } \\
\text { ad S }\end{array}$ & & \\
\hline 7 & $\begin{array}{l}\text { Merkuri } \\
\text { Axsl } \\
\text { Wardani }\end{array}$ & 9 & Sedang \\
\hline 8 & $\begin{array}{l}\text { M. Razan } \\
\text { Yuwono } \\
\text { P }\end{array}$ & 9 & Sedang \\
\hline 9 & M. Helmi & 6 & Rendah \\
\hline 10 & $\begin{array}{l}\text { M. Risal } \\
\text { karim }\end{array}$ & 8 & Sedang \\
\hline 11 & $\begin{array}{l}\text { Rayhan } \\
\text { Faiz }\end{array}$ & 9 & Sedang \\
\hline & $\begin{array}{l}\text { Rata - } \\
\text { rata } \\
\text { keaktifan } \\
\text { siswa }\end{array}$ & 8 & Sedang \\
\hline & \multicolumn{3}{|c|}{$\begin{array}{c}\text { 63,63\% siswa aktif mengikut } \\
\text { kegiatan pembelajaran } \\
\text { (sedang } 54,54 \%+\text { tinggi } 9,09 \%) \\
\text { dan } \\
\text { 36,36 \% siswa dalam } \\
\text { kategori rendah }\end{array}$} \\
\hline
\end{tabular}

Tabel 4. Rekapitulasi Data Keaktifan Siswa Pra Siklus dan Siklus I

\begin{tabular}{|c|l|c|c|}
\hline No & $\begin{array}{l}\text { Data } \\
\text { Keaktifan }\end{array}$ & Siklus I & Persentase Siklus I \\
\hline 1 & Tinggi & 1 dari 11 anak & $9,09 \%$ \\
\hline 2 & Sedang & 6 dari 11 anak & $54,54 \%$ \\
\hline 3 & Rendah & 4 dari 11 anak & $36,36 \%$ \\
\hline
\end{tabular}

Hasil yang diperoleh sebagian besar siswa menunjukkan keaktifan yang lebih baik dibandingkan dengan keaktifan siswa pada saat observasi awal sebelum tindakan. Hal ini menunjukkan bahwa keaktifan belajar siswa di kelas XII IPS dalam mata pelajaran Sosiologi meningkat. Jadi hasil observasi pada siklus I menurut 
katagori diatas adalah termasuk katagori cukup. Setelah hasil diketahui maka perlu dilakukan refleksi untuk mengkoreksi kelemahan dan kendala yang terjadi pada siklus I kemudian mencari solusi yang nanti akan diterapkan pada siklus II dengan harapan hasilnya mengalami peningkatan. Jadi hasil observasi pada siklus I menurut katagori diatas adalah termasuk katagori cukup. Setelah hasil diketahui maka perlu dilakukan refleksi untuk mengkoreksi kelemahan dan kendala yang terjadi pada siklus I kemudian mencari solusi yang nanti akan diterapkan pada siklus II dengan harapan hasilnya mengalami peningkatan.

Dalam pelaksanaan siklus II, peneliti melakukan langkah-langkah yang sama dengan langkah-langkah pada siklus I namun ada perbaikan pelaksanaan berdasarhan hasil refleksi pada siklus I. Dalam pembelajaran siklus II, peneliti mengharapkan peran serta keaktifan siswa dalam pembelajaran, dengan menggunakan media slide share dalam quizizz. Slide share yang dipadukan dengan quiz, cara ini sangat terbukti baik dalam mendongkrak aktifitas siswa dalam pembelajaran. Dalam siklus II ini, siswa juga diberikan LKPD yang lebih interaktif, dengan menambahkan tugas pembuatan poster yang kemudian dipresentasikan oleh masing-masing siswa dengan penunjukan secara random. Berdasarkan hasil pertemuan ke-1 pada siklus II siswa yang aktif dalam pembelajaran dan mengerjakan kuis sebanyak 8 siswa $(72,27 \%)$, sedangkan pada pertemuan ke-2 siswa yang aktif 9 siswa $(81,81 \%)$. Rata-rata hasil observasi pada siklus II adalah $77,04 \%$. Hasil siklus II termasuk dalam katagori tinggi. Dari hasil observasi suklus I dan siklus II keaktifan siswa mengalami peningkatan sebesar 26,91\%. Berikut tabel rekapitulasi keaktifan siswa kelas XII IPS pada siklus I dan siklus II.

Hasil yang diperoleh sebagian besar siswa menunjukkan keaktifan yang lebih baik dibandingkan dengan keaktifan siswa pada saat pelaksaaan kegiatan pembelajaran sosiologi pada siklus I. Hal ini menunjukkan bahwa keaktifan siswa kelas XII IPS meningkat dan mampu memperoleh nilai persentase keaktifan yang ditargetkan dalam mengikuti pembelajaran sosiologi. Berdasarkan hasil observasi terhadap keaktifan siswa dalam mengikuti kegiatan pembelajaran sosiologi melalui pembelajaran dengan 
model game based learning pada siklus II, adalah sebagai berikut:

(a) Proses pembelajaran sosiologi sudah sesuai dengan rencana pelaksanaan pembelajaran yang sudah dirancang. Siswa tampak sudah mampu melakukan kegiatan pembelajaran dengan baik, menunjukkan keaktifan dan berusaha untuk menyelesaikan semua tugas yang diberikan oleh guru.

(b) Pembelajaran sosiologi melalui pembelajaran dengan model game based learning sudah dilaksanakan dengan baik dan sistematis. Hasil observasi keaktifan siswa meningkat dibandingkan dengan keaktifan sebelum menggunakan pendekatan keterampilan proses.

(c) Sebagian besar siswa sudah tampak aktif, siswa yang semula (pada siklus I) belum mampu berpartisipasi secara aktif sudah terbiasa dengan pembelajaran dengan model game based learning sehingga tampak menunjukkan keaktifannya.

(d) Proses pembelajaran lebih interaktif antara guru dengan siswa. Terlihat dari data aspek aktifitas siswa meningkat dibanding sebelum menggunakan pembelajaran dengan model game based learning. Siswa juga sudah tidak tampak canggung untuk bertanya ataupun menggukakan pendapatnya.

Tabel 5

Rekapitulasi hasil observasi keaktifan siswa

\begin{tabular}{|c|c|c|c|c|c|}
\hline $\mathbf{N}$ & $\begin{array}{l}\text { Sik } \\
\text { lus }\end{array}$ & $\begin{array}{l}\text { Perte } \\
\text { muan } \\
\text { Ke } 1\end{array}$ & $\begin{array}{l}\text { Perte } \\
\text { muan } \\
\text { Ke } 2\end{array}$ & $\begin{array}{c}\text { Rat } \\
\text { a- } \\
\text { rata }\end{array}$ & $\begin{array}{r}\text { Kate } \\
\text { gori }\end{array}$ \\
\hline 1 & I & $\begin{array}{c}36,36 \\
\%\end{array}$ & $\begin{array}{c}63,63 \\
\%\end{array}$ & $\begin{array}{l}50,1 \\
3 \%\end{array}$ & $\begin{array}{c}\text { Seda } \\
\text { ng }\end{array}$ \\
\hline 2 & II & $\begin{array}{c}72, \\
27 \%\end{array}$ & $\begin{array}{c}81,81 \\
\%\end{array}$ & $\begin{array}{l}77,0 \\
4 \%\end{array}$ & $\begin{array}{c}\text { Ting } \\
\text { gi }\end{array}$ \\
\hline \multicolumn{4}{|c|}{ Peningkatan } & $\begin{array}{c}26,9 \\
1 \%\end{array}$ & \\
\hline
\end{tabular}

Berdasarkan table tersebut, maka dapat digambarkan grafik seperti :

\section{Hasil Observasi Keaktifan Siswa}

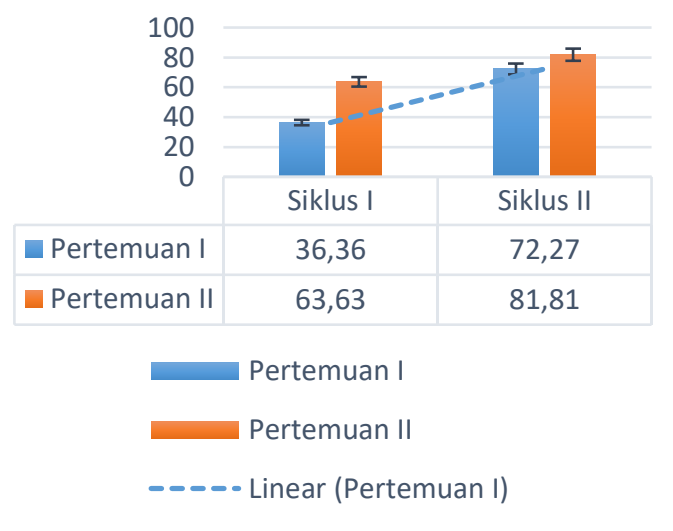


Penelitian tindakan kelas yang dilakukan melalui dua siklus ini dilakukan untuk mengetahui apakah penerapan pembelajaran dengan menggunakan game based learning untuk meningkatkan keaktifan belajar siswa dalam mengikuti kegiatan pembelajaran sosiologi di kelas XII IPS SMA Darul Hikmah Kutoarjo berhasil atau kurang berhasil. Adapun peningkatan skor keaktifan siswa berdasarkan hasil observasi awal, siklus I serta siklus II sebagai berikut : Berdasarkan hasil penelitian dapat dilihat dari ketuntasan hasil belajar siswa yang mengalami kenaikan dari pra siklus siklus I - siklus II dilihat dari kenaikan tersebut, maka hal ini termasuk kategori signifikan. Hasil penelitian tersebut sesuai dengan yang diharapkan oleh peneliti yaitu terciptanya keaktifan dalam proses pembelajaran seperti : siswa mengajukan pertanyaan, aktif berdiskusi dan memberikan simpulan pembelajaran. Dimana materi dan model pembelajaran sangat relevan sehingga dapat membantu proses belajar mengajar dikelas menjadi lebih baik. Dalam indikator pencapaian, kegiatan pembelajaran ini dapat menarik keaktifan belajar siswa dan masuk dalam kategori sangat kuat yaitu perubahan perhatian siswa menjadi sangat baik dalam kegiatan pembelajaran. Untuk indikator kepuasan, siswa merasa lebih tertantang dalam pengerjaan kuis, semangat dalam mengajukan pertanyaan pada kegiatan belajar mengajar dikelas sehingga suasana dikelas menjadi efektif. Sedangkan untuk kepercaan diri, dalam hal ini siswa mempunyai keinginan untuk melakukan kegiatan belajar dalam kelas sehingga dapat membantu proses pembelajaran dikelas menjadi lebih baik.

Hal tersebut dapat dilihat dengan adanya peningkatan prestasi belajar siswa saat mengikuti post test dengan media kuis interaktif serta motivasi siswa pada kegiatan pembelajaran. Dengan adanya hasil penelitian terdahulu dapat disimpulkan bahwa terdapat adanya hasil peningkatan aktivitas pembelajaran siswa dalam implementasi model pembelajaran Game based learning dimana Game based learning ini sangat efektif dalam meningkatkan hasil belajar siswa.

Tabel 4.13 Indikator Keberhasilan Penelitian

\begin{tabular}{|l|l|l|l|l|}
\hline No & Indicator & $\begin{array}{c}\text { Pra } \\
\text { siklus }\end{array}$ & Siklus I & \multicolumn{1}{|c|}{$\begin{array}{c}\text { Siklus } \\
\text { III }\end{array}$} \\
\hline 1 & $\begin{array}{l}\text { Memperh } \\
\text { atikan }\end{array}$ & $\begin{array}{l}\text { Siswa } \\
\text { yang }\end{array}$ & $\begin{array}{l}\text { Siswa } \\
\text { yang }\end{array}$ & $\begin{array}{l}\text { Siswa } \\
\text { yang }\end{array}$ \\
\hline
\end{tabular}




\begin{tabular}{|c|c|c|c|c|}
\hline & $\begin{array}{l}\text { penjelasa } \\
\text { n guru }\end{array}$ & $\begin{array}{l}\text { memper } \\
\text { hatikan } \\
\text { penjelas } \\
\text { an guru } \\
\text { kurang } \\
\text { dari } 30 \\
\%\end{array}$ & $\begin{array}{l}\text { memperh } \\
\text { atikan } \\
\text { penjelasa } \\
\text { n guru } \\
\text { kurang } \\
\text { dari } 60 \%\end{array}$ & $\begin{array}{l}\text { memper } \\
\text { hatikan } \\
\text { penjelas } \\
\text { an guru } \\
\text { lebih } \\
\text { dari } \\
75 \%\end{array}$ \\
\hline 2 & $\begin{array}{l}\text { Mengaju } \\
\text { kan } \\
\text { pertanyaa } \\
\text { n }\end{array}$ & $\begin{array}{l}\text { Siswa } \\
\text { yang } \\
\text { berani } \\
\text { mengaju } \\
\text { kan } \\
\text { pertanya } \\
\text { an } \\
\text { kurang } \\
\text { dari } 30 \\
\%\end{array}$ & $\begin{array}{l}\text { Siswa } \\
\text { yang } \\
\text { berani } \\
\text { mengajuk } \\
\text { an } \\
\text { pertanyaa } \\
\text { n kurang } \\
\text { dari } 45 \%\end{array}$ & $\begin{array}{l}\text { Siswa } \\
\text { yang } \\
\text { berani } \\
\text { mengaju } \\
\text { kan } \\
\text { pertanya } \\
\text { an lebih } \\
\text { dari } 60 \\
\%\end{array}$ \\
\hline 3 & $\begin{array}{l}\text { Menjawa } \\
\mathrm{b} \\
\text { pertanyaa } \\
\mathrm{n}\end{array}$ & $\begin{array}{l}\text { Siswa } \\
\text { yang } \\
\text { berani } \\
\text { menjaw } \\
\text { ab } \\
\text { pertanya } \\
\text { an dari } \\
\text { guru } \\
\text { kurang } \\
30 \%\end{array}$ & $\begin{array}{l}\text { terdapat } \\
40 \quad \% \\
\text { siswa } \\
\text { menjawab } \\
\text { pertanyaa } \\
\text { n dari } \\
\text { guru. }\end{array}$ & $\begin{array}{l}\text { terdapat } \\
\text { lebih } \\
\text { dari } \\
60 \% \\
\text { siswa } \\
\text { menjaw } \\
\text { ab } \\
\text { pertany } \\
\text { aan dari } \\
\text { guru. }\end{array}$ \\
\hline 4 & $\begin{array}{l}\text { Mengem } \\
\text { ukakan } \\
\text { pendapat }\end{array}$ & $\begin{array}{l}\text { Siswa } \\
\text { yang } \\
\text { berani } \\
\text { mengem } \\
\text { ukakan } \\
\text { pendapa } \\
\mathrm{t} \quad \text { saat } \\
\text { proses } \\
\text { pembela } \\
\text { jaran } \\
\text { dan } \\
\text { berdisku } \\
\text { si } \\
\text { kelompo } \\
\mathrm{k} \text { hanya } \\
\text { sebesar } \\
30 \%\end{array}$ & $\begin{array}{l}\text { terdapat } \\
50 \\
\text { siswa } \\
\text { mampu } \\
\text { mengemu } \\
\text { kakan } \\
\text { pendapat } \\
\text { saat } \\
\text { pembelaja } \\
\text { ran dan } \\
\text { berdiskusi } \\
\text { kelompok }\end{array}$ & $\begin{array}{l}\text { Terdapa } \\
\mathrm{t} \text { lebih } \\
\text { dari } \\
60 \% \\
\text { siswa } \\
\text { menge } \\
\text { mukaka } \\
\mathrm{n} \\
\text { pendapa } \\
\mathrm{t} \quad \text { saat } \\
\text { pembela } \\
\text { jraran } \\
\text { dan } \\
\text { berdisk } \\
\text { usi } \\
\text { kelomp } \\
\text { ok. }\end{array}$ \\
\hline 5 & $\begin{array}{l}\text { Mendeng } \\
\text { arkan }\end{array}$ & $\begin{array}{l}\text { Siswa } \\
\text { yang }\end{array}$ & $\begin{array}{l}\text { terdapat } \\
\text { lebih dari }\end{array}$ & $\begin{array}{l}\text { Lebih } \\
\text { dari }\end{array}$ \\
\hline
\end{tabular}

\begin{tabular}{|c|c|c|c|c|}
\hline & $\begin{array}{l}\text { penjelasa } \\
\mathrm{n} \text { guru }\end{array}$ & $\begin{array}{l}\text { menden } \\
\text { garkan } \\
\text { penjelas } \\
\text { an guru } \\
\text { sebesar } \\
60 \%\end{array}$ & $\begin{array}{l}60 \quad \% \\
\text { siswa } \\
\text { mendenga } \\
\text { rkan } \\
\text { penjelasa } \\
\text { n guru. }\end{array}$ & $\begin{array}{l}85 \% \\
\text { siswa } \\
\text { menden } \\
\text { garkan } \\
\text { penjelas } \\
\text { an guru. }\end{array}$ \\
\hline 6 & $\begin{array}{l}\text { Diskusi } \\
\text { kelompok }\end{array}$ & $\begin{array}{l}\text { Siswa } \\
\text { yang } \\
\text { terlibat } \\
\text { aktif } \\
\text { diskusi } \\
\text { kelompo } \\
\text { k kurang } \\
\text { dari 50 } \\
\%\end{array}$ & $\begin{array}{l}\text { terdapat } \\
60 \\
\text { siswa } \\
\text { aktif } \\
\text { berdiskusi } \\
\text { kelompok }\end{array}$ & $\begin{array}{l}\text { terdapat } \\
\text { lebih } \\
\text { dari } 80 \\
\% \text { siswa } \\
\text { aktif } \\
\text { berdisk } \\
\text { usi } \\
\text { kelomp } \\
\text { ok. }\end{array}$ \\
\hline
\end{tabular}

\section{DISKUSI}

Konsep dalam penelitian ini mengacu pada game based learning yang merupakan teknik pembelajaran berlandasan permainan yang dapat membantu meningkatkan potensi dan kualitas pelajar dalam menyerap pengetahuan. Ryan Dellos (2015), menyatakan bahwa pembelajaran berlandasan permainan merupakan alat yang dapat membantu peserta didik dalam menyelesaikan masalah, meningkatkan pemikiran kritis dan membuat sebuah penilaian dalam proses pembelajaran. Huang (2011), menyatakan penelitian pada bidang desain pendidikan telah menunjukkan bahwa game based learning atau pembelajaran berbasis permainan adalah 
salah satu alat yang efektif dalam

pengajaran terutama untuk menjaga motivasi keberlanjutan belajar.

Pembelajaran di SMA Darul Hikmah

Kutoarjo masih minim dalam penggunaan aplikasi interaktif untuk menarik perhatikan dari peserta didik.

Guru hanya menggunakan media papan tulis dan power point sebagai media dalam menjelaskan materi kepada peserta didik. Ketika penyampaian pelajaran oleh guru, disini guru hanya menggunakan model konvensional, menjelaskan melalui power points serta diskusi tanya jawab sehingga terkesan membosankan dan kurang menarik minat siswa. Belum digunakannya variasi model dan media pembelajaran secara maksimal menyebabkan proses pembelajaran terkesan monoton. Setelah menggunakan game based learning dengan aplikasi quizizz serta mencermati peningkatan keaktifan proses belajar pada mata pelajaran sosiologi kelas XII IPS SMA Darul Hikmah Kutoarjo, maka tidak menutup kemungkinan model pembelajaran ini diterapkan juga pada mata pelajaran lain di SMA Darul Hikmah Kutoarjo. Dalam pra siklus sampai dengan siklus II dilakukan secara daring, sehigga observer tidak mengetahui secara detail tentang keaktifan siswa. Hanya bisa memastikan dengan media google meet untuk melihat perkembangan melalui catatan dah hasil diskusi. Jumlah siswa yang terlalu sedikit, hanya 11 siswa saja sehingga membuat penelitian hanya sederhana. Setelah dilaksanakan penelitian di SMA Darul Hikmah maka diharapkan agar Guru dapat menerapkan pembelajaran model pembelajaran Game based learning pada pelajaran yang lain, sebagai variasi pembelajaran di kelas agar siswa tidak jenuh. Siswa diharapkan lebih aktif lagi dalam mengikuti pelajaran, seperti aktif bertanya, aktif menjawab pertanyaan dari guru, aktif mengemukakan pendapat, aktif bekerja sama dalam kelompok, dan lain sebagainya. Siswa diharapkan mampu mengembangkan kemampuan berkomunikasi, bekerja sama dalam kelompok, saling memberi semangat agar tercipta ketergantungan positif.

\section{KESIMPULAN}

Penerapan model pembelajaran 
Game based learning pada mata pelajaran Sosiologi kelas XII IPS SMA Darul Hikmah Kutoarjo dapat meningkatkan keaktifan belajar siswa. Hal tersebut dapat dilihat dari tiap siklus keaktifan siswa yang meningkat dari pra siklus dengan siklus I rata - rata $50,13 \%$ dan siklus II rata - rata $77,04 \%$ dengan peningkatan $26,91 \%$ termasuk dalam kategori tinggi. Penerapan model pembelajaran game based leraning pada mata pelajaran sosiologi kelas XII IPS SMA Darul Hikmah Kutoarjo, terbukti efektif untuk meningkatkan tingkat keaktifan siswa dalam proses pembelajaran, sehingga metode ini bisa diaplikasikan untuk mata pelajaran lain dengan cara yang lebih interaktif lagi.

\section{DAFTAR PUSTAKA}

Arikunto, Suharsimi, dkk. (2010). Penelitian Tindakan Kelas. Jakarta: Bumi Aksara. Azhar Arsyad. (2013). Media Pembelajaran. Jakarta: PT. Raja Grafindo Persada.

Aunurrahman. (2009). Belajar dan Pembelajaran. Bandung: Alfabeta.

Depdiknas. (2003). Undang-undang RI No.20 tahun 2003 tentang sistem pendidikan nasional.

Fauziyyah, U. (2019). Pengaruh Media Quizizz terhadap Motivasi Belajar Peserta Didik dalam Pembelajaran PKn (Quasy Experiment di SMA Negeri 1 Majalaya Kab. Bandung) (Doctoral dissertation, FKIP UNPAS). Diakses dari http//repository.unpas.ac.id/43342/

Hardjito. (2002). Internet untuk pembelajaran. Jurnal Teknologi Pendidikan. Edisi No. 10/VI/Teknodik/Oktober/2002. Jakarta: Pusat Teknologi Komunikasi dan Informasi Pendidikan Depdiknas.

Martinis Yamin. (2007). Kiat Membelajarkan Siswa. Jakarta. Gaung Persada Press dan Center for Learning Innovation (CLI).

Oemar Hamalik. (2008). Kurikulum Dan Pembelajaran. Jakarta: Bumi Akasra.

Purba, Leony Sanga. (2019). Peningkatan Konsentrasi Belajar Mahasiswa Melalui Pemanfaatan Evaluasi Pembelajaran Quizizz pada Mata Kuliah Kimia Fisika I. Jurnal Dinamika Pendidikan (http://garuda.ristekbrin.go.id/documents/detail/1027383)

Ryan Dellos. (2015). Kahoot! A digital game resource for learning. In International Journal of Instructional Technology and Distance Learning Vol 12 (pp. 49-52). Retrieved from (https://scholar.google.co.kr/citations?user=irAHXE4AAAAJ\&hl=en\#d=gs_md_cita- 
$\mathrm{d} \& \mathrm{p}=\& \mathrm{u}=\% 2 \mathrm{Fcitations} \% 3 \mathrm{Fview}$ _op\%3Dview_citation\%26h1\%3Den\%26user\%3DirAHXE4 AAAAJ\%26citation_for_view\%3DirAHXE4AAAAJ\%3Au5HHmVD_uO8C\%26tzom\%3D$\underline{420})$

Sihaan, Sudirman. E-Learning (pembelajaran Elektronik) sebagai salah Satu Alternatif Kegiatan Pembelajaran. Jurnal Pendidikan dan Kebudayaan No. 042-Mei 2003. Jakarta: Depdiknas.

Slameto. (2010). Belajar Dan Faktor-Faktor Yang Mempengaruhi. Jakarta: Rineka Cipta.

Solikah, Halimatus. (2019). Pengaruh Penggunaan Media Pembelajaran Interaktif Quizizz terhadap Motivasi dan Hasil Belajar Siswa pada Materi Teks Persuasif Kelas VIII di SMPN 5 Sidoarjo Tahun Pelajaran 2019/2020. Jurnal PTK Unesa

Suo Yan mei, S. Y. (2018). Implementing Quizizz as Game based learning in the Arabic Classroom. Journal of Social Sciences Education and Research, 208-212.

Sudjana, Nana. (2014). Penilaian Hasil Proses Belajar Mengajar. Bandung: Rosdakarya.

Sukidin, dkk., 2002. Manajemen Penelitian Tindakan Kelas. Jakarta: Insan. Cendekia.

Takari, Enjah. (2010). Penelitian Tindakan Kelas. Bandung: PT. Genesindo

Wiriaatmadja, R. (2009). Metode Penelitian Tindakan Kelas. Bandung : PT Remaja Rosdakarya. 